\title{
Visualizing data on graphic memory research
}

\section{Priscila Lena Farias}

\author{
My only point is my method, which I always insist on \\ in anything in bibliography - \\ arrange your facts rigorously and get them \\ plainly before you, and let them speak for themselves, \\ which they will always do. \\ -Henry Bradshaw (Prothero,1888: 349)
}

\section{INTRODUCTION}

This is not a paper about computer parts or about technical aspects of computational systems. Graphic memory is here understood as "a line of studies that intends to review the significance and value of visual artifacts, and in particular of printed ephemera, in the establishment of a sense of local identity through design" (Farias, 2015, p. 201), therefore contributing to the design of local graphic design history. Graphic memory research is always concerned with the visual, material and semantic aspects of graphic artifacts, using those artifacts as primary sources and central documents. The material nature of graphic artifacts allow them to be not only analysed in terms of its visual and physical attributes, but also as spatially situated and geographically located phenomena.

In other occasions, I have discussed the way in which the study of commercial almanachs and type specimens could contribute to graphic memory and design history (Farias, Aragão and Cunha Lima, 2012), and the benefits of historical GIS to research on print culture (Farias, Hanns and Dixon, 2016). Here, I will resume some of the ideas discussed in those earlier works, and put forward considerations on approaches to the visualization of data, having as a case study the development of a website on São Paulo city early print culture.

The "Tipografia Paulistana" ${ }^{1}$ website is one of the recent results of a wider line of research on São Paulo city graphic memory, that integrates the Memória Gráfica Brasileira (Brazilian Graphic Memory) research network. The network

\footnotetext{
1 Accessible at $<$ http://labvisual.fau.usp.br/tipografiapaulistana>.
} 
started as a research project, active from 2008 to 2013, resulting in comparative studies developed between nodes located in Recife, Rio de Janeiro and São Paulo. Some of the main interests of the original Memória Gráfica Brasileira research project were printed ephemera and graphic artifacts produced in the early days of Brazilian industrialization, leading to a number of investigations on the microhistory of early print culture and typography in various parts of Brazil.

Derived from the Memória Gráfica Brasileira project, the research line Memória Gráfica Paulistana (São Paulo city Graphic Memory) started, in 2011, with an exploratory investigation on the visual characteristics presented by typographic artifacts produced in São Paulo city, resulting in a database accessible through a first version of the Tipografia Paulistana website. It went on to engage a growing number of students and investigators, ${ }^{2}$ dedicated to studies on printing in São Paulo in the nineteenth and early twentieth century, and to the development of an improved version of the website.

The first letterpress printing shop established in São Paulo, in 1827, was responsible for printing the newspaper O Farol Paulistano, and came to be known by the same name. The subsequent expansion and growing relevance of printing in São Paulo city was registered in the early twentieth century by Affonso A. de Freitas (1915), who listed 22 newspapers being published in the city until 1840, 55 new titles between 1851 and 1860, and other 273 between 1881 and 1890 (Freitas 1915, p. 17). Towards the end of the nineteenth century, São Paulo became more and more relevant in terms of economy, education and politics, and this was accompanied by a growing number of printing shops (Hallewell 1985, Deaecto 2002, Cruz 2004). According to Artur Vitorino, the first typesetting machine was installed in São Paulo in 1905 (Vitorino 2000), causing revolt among typesetters afraid of losing their jobs, but gradually becoming the norm for books and newspaper production, leading to an end the golden era of manual typesetting and printing with movable type.

The time frame chosen for the research that resulted in the Tipografia Paulistana website (1827-1927), therefore, was defined taking into account the 100 years that go from the establishment of the first printing shop in the city, to the

2 The complete team included professors Priscila L. Farias (coordinator), Daniela K. Hanns and Leandro Velloso (FAU USP, Brazil), Catherine Dixon (UAL/CSM, UK), and Isabella Aragão (UFPE, Brazil); undergraduate students Alessandra Fudoli, Aline K. Yoshimatsu, Bianca T. Martins, Clara O. Gastelois, Deu Rim Choi, Heloisa B. Oliveira, Janaina de F. Oliveira, Marina A. Onoda, Olivia L. Cavallari, Paola R. Fernandes, Roberta A. Cunha; postgraduate students Fabio M. C. Pereira and Laura B. Lotufo; programmer Mauricio Galdieri; and research assistant Marcella M. Jyo. 
beginning of the period when manual typesetting started to be replaced by mechanic composition.

The main questions set up for the research were:

1. WHO? (who were the first São Paulo letterpress printers, and who provided type for those printers?)

2. WHEN? (when were they printing, and when were the typefaces incorporated to their repertoire?)

3. WHERE? (where the printing shops and type foundries or distributors were located?)

4. WHAT? (what typefaces were they using?)

Differently from almanacs dedicated to culture and entertainment (like the also popular 'literary' almanachs), Brazilian nineteenth century 'commercial' almanacs were a form of annual publication systematically listing, among other things, main trades and accredited professionals (Farias, Aragão and Cunha Lima, 2012, p. 500). Lists of printing shops, frequently accompanied by their addresses, names of owners and staff, and current publications were provided in each edition. Type specimens, on the other hand, by cataloguing the repertoire of typefaces, ornaments and vignettes of a print office or type foundry, are a rich source of information on the subject (Farias, Aragão and Cunha Lima, 2012: 503). Data for answering questions 1,2 and 3 were to be found, therefore, in commercial almanachs, and type specimens be the best place to look for answers to question 4.

While data was being gathered, strategies for its visualization started to be conceived. Organizing data is a first step towards analisis, and the tools and methods adopted from this phase on are key for finding trends, counter-trends, coincidences and deviations that base interpretation. Arranging data in spreadsheets, treating and organizing image files are already pathways towards the visualization of data, and finally resulted in the interactive maps, timelines and dynamic typeface specimens that were included in the Tipografia Paulistana website.

\section{GATHERING AND VISUALIZING DATA ON EARLY PRINTERS AND TYPE FOUNDERS}

The best known Brazilian nineteenth century commercial almanac series Almanach Laemmert-, published in Rio de Janeiro, is available at the Brazilian National Library, also online. The situation is different for commercial almanacs published in São Paulo in the same period. As noted also by Camargo (1983), no library or archive holds a complete collection of them, and an extensive search in different libraries and archives was necessary in order to come up with a reliable list. 
Fourteen issues, from three different commercial almanac series, published

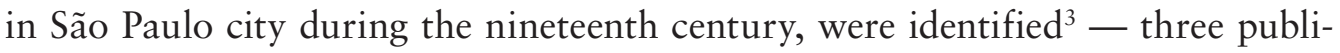
shed by Typographia Imparcial de Marques and Irmão (two almanachs for years 1857 and 1858, and a 'memorial' for year 1866), one by Typographia Americana (for year 1873), eleven by Jorge Seckler and his successors (an 'indicador' for 1878, and nine almanachs, for years 1883, 1884, 1885, 1887, 1888, 1890, 1891, 1895 and 1896).

The strategy adopted for gathering data in nineteenth century commercial almanacs included bibliographical and documental research techniques. Each almanac was examined in search for information on printing offices (typographias) and type founders (fundições de typos), both in the address listings and in the advertising (notabilidades) sections. Data gathered from the nineteenth century commercial almanachs was complemented with data found in almanachs and trade magazines published in the early twentieth century, and information found on secondary sources, such as Affonso A. de Freitas comprehensive list of newspapers published from 1827 to 1914 (Freitas, 1915). Data from 270 letterpress printers, 14 type founders or distributors, and almost 40 related companies (such as book binders and lithographic printers) was found. Documental research techniques were used for gathering data on the typefaces used by the printers of the almanachs, as described in the next topic.

Shared online spreadsheets provided by Google were used for organizing and comparing data. The first versions of those spreadsheets contained only a few columns for basic information such as year, name of the company, address, publications, staff and notes. They went on to contain 19 columns used for registering more complex data such as the first and the last year of activity, of each company, and the different addresses and activities they announced. An interactive map, associated with a timeline, was considered to be the best way to visualize this data.

\section{GATHERING AND VISUALIZING DATA ON TYPOGRAPHIC REPERTOIRES}

Research on typeforms and typographic repertoires is frequently done through the examination of printers and type founders catalogues (see, for instance, Gray, 1976 [1938], Annemberg, 1994 [1975], and Vervliet, 2008). Such publications, however, due to their commercial and temporary aspect, have not been

3 Archives consulted were those at Biblioteca Mário de Andrade (BMA), Faculdade de Direito da Universidade de São Paulo (FD USP), Instituto de Estudos Brasileiros (IEB USP) and Biblioteca Brasiliana Guita e José Mindlin (BBM USP). 
preserved with the same systematicity and care as books in libraries. In fact, although ten type specimens printed in Brazil in the nineteenth century could be found (nine in the Brazilian National Library and one in the Historical and Geographical Institute, Cunha Lima, Aragão and Farias, 2013), none of them were printed in São Paulo.

The strategy for gathering data from type specimens is based mostly on documental research, and requires special methods and procedures (Farias, Aragão and Cunha Lima, 2012). If the volumes that have to be taken into account are hold in different archives, images in high resolution of type samples are needed for performing comparisons that will determine, for example, if the same typeface was available from more than one type founder or was present in the repertoire of different printers, or of the same printer through time. The same is true if, instead of working from type specimens one wants or needs (as it was the case in the research described here) to extract and compare samples from other printed matter (like books, almanachs or newspapers).

Commercial almanachs were a kind of publication that required a good sense of typographic identity, hierarchy and differentiation from its printers. Those responsible for their design would certainly take into account the need for some level of visual coherence among different volumes of the same collection; a moderate level of visual contrast that would allow readers to browse and find information from different tables and lists; and for an expressive sense of novelty and diversity in the products and services announced in the 'notabilidades' pages. The level of typographic expressivity and differentiation found in those last pages is only comparable to that found in nineteenth century posters or title pages, where printers would sometimes use a different typeface for each line - just like in type specimens.

The printers of commercial almanachs where therefore selected to be the first to have their typographic repertoire investigated and inventoried. Pages from the almanachs published by Seckler and Marques and Irmão printing shops were photographed or scaned in high resolution. Letters, numbers and orthographic signs found in those pages were separated and then combined to recreate the fonts (typefaces in specific sizes and styles) and type families (groups of fonts with the same design) found in the publications. This allowed for comparisons between typefaces found in the printers' repertoires and in type specimens (Farias and Onoda 2015) and also between the repertoires of different printers (Farias and Cunha Lima 2016).

Dynamic type specimens, digitally recreated from the images of typefaces, vignettes and ornaments found in almanachs, books and newspapers, were considered by the research team the best way to visualize the printers' typographic repertoires. 


\section{MAKING IT ALL VISIBLE IN A WEBSITE}

Tipografia Paulistana is a website that gives access to a database on the first 100 years of letterpress printing in São Paulo city, developed in PostgreSQL, and hosted in an Apache server at FAU USP. Although an important part of this database is verbal or numerical, it also includes relevant visual and geographical information. The website is divided in three main areas (Typefaces, Companies and People), and navigation within them is done through three main modes (lists, maps and 'mosaics').

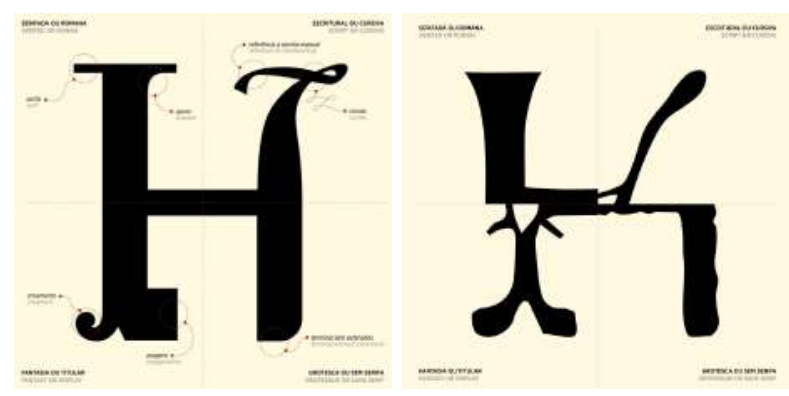

Figures 1a and 1b: Two moments of the animated diagram in Tipografia Paulistana home page.

In the homepage, an animated diagram (Figure 1a) explains the nomenclature used for the 4 main categories of type i the website (serifed or roman, grotesque or sans serif, script or cursive, fantasy or display). Examples of parts of letters $\mathrm{H}$ in those different categories alternate with the explanation (Figure 1b).

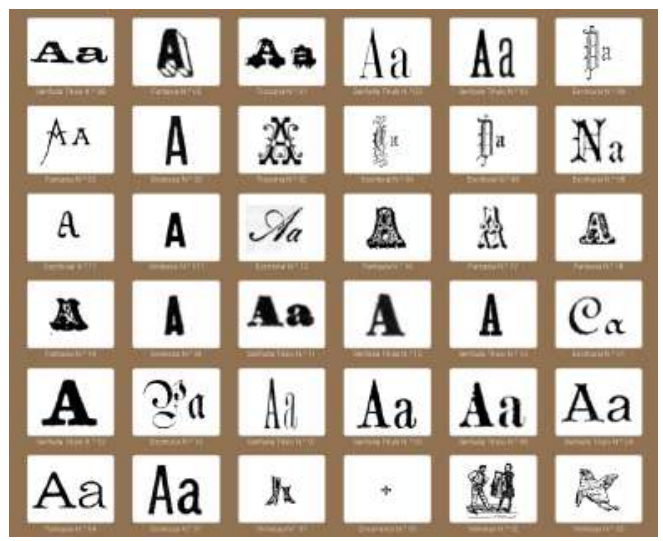

Figure 2: Aspect of the 'mosaic' of type and ornament families in the Typefaces area. 
In the Typefaces area, the main mode of navigation is a 'mosaic': a set of images representing type families or collections of ornaments (Figure 2). Filters, based on Dixon's (2001) typeform description framework, can be applied to select type or ornament families with certain characteristics. It is also possible to navigate from an interactive map, similar to the one available in the companies area.

Clicking in one of the elements of the mosaic gives access to type family pages. Similar to type specimen pages where samples of different body sizes and styles (for instance, roman and italic, Figure 3a) of the same typeface are composed from characters gathered in almanachs, books and newspapers (Figure 3b). Ornaments and vignettes were also organized in 'families' (Figure 4). In order to achieve that, images collected were associated with metadata that describe their formal attributes (such as shape and size), and organized in virtual type racks and type cases in the website content management system.

The type families pages list the publications where the samples were found, and also the printers responsible for those publications. Clicking on a printers' name gives access to the company page (also accessible from the Companies area, Figure 5). Information on the activity of printers are to be found in these pages, along with a map showing their address (or addresses) and typographic repertoire 'mosaic'.

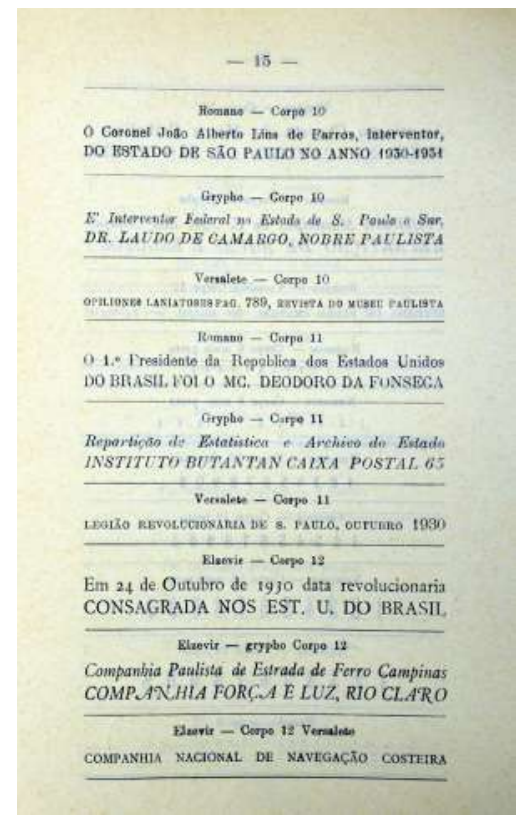

\begin{tabular}{|c|c|}
\hline & Serifada Texto $N^{\circ} 02$ \\
\hline & ressos \\
\hline & 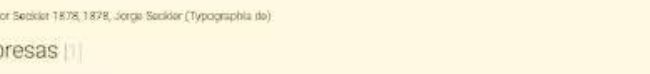 \\
\hline$\infty$ & armes \\
\hline 100 & A C DEGIL M NOQRSTUVI 2 . \\
\hline 130 & $\begin{array}{l}\text { A BCFGJNRSaáadehilm n } \\
\text { oprstuzo1239., }\end{array}$ \\
\hline${ }_{120}$ & $\begin{array}{l}\text { A B C Ç D E F I M N OPQR T T Z } \\
\tilde{A} \hat{\mathrm{E}}\end{array}$ \\
\hline 128 & ABDEINORSTUVO6.- \\
\hline 175 & 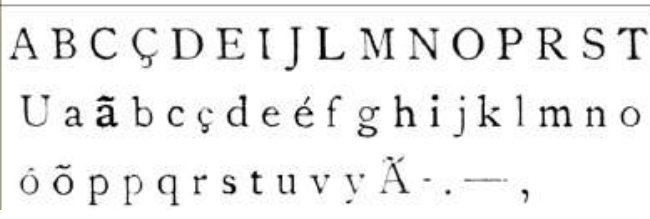 \\
\hline
\end{tabular}

Figures 3a and 3b: Type samples in a printed early twentieth century type specimen (Imprensa Oficial de São Paulo, 1931), and in the Tipografia Paulistana website. 


\section{Ornamento N ${ }^{0} 10$}

\section{Impressos}

Almanaque Seckler, 1887, Jorge Seckler (Typographia de)

https //digital bbm usp br/handle/bbm/568

\section{Empresas}

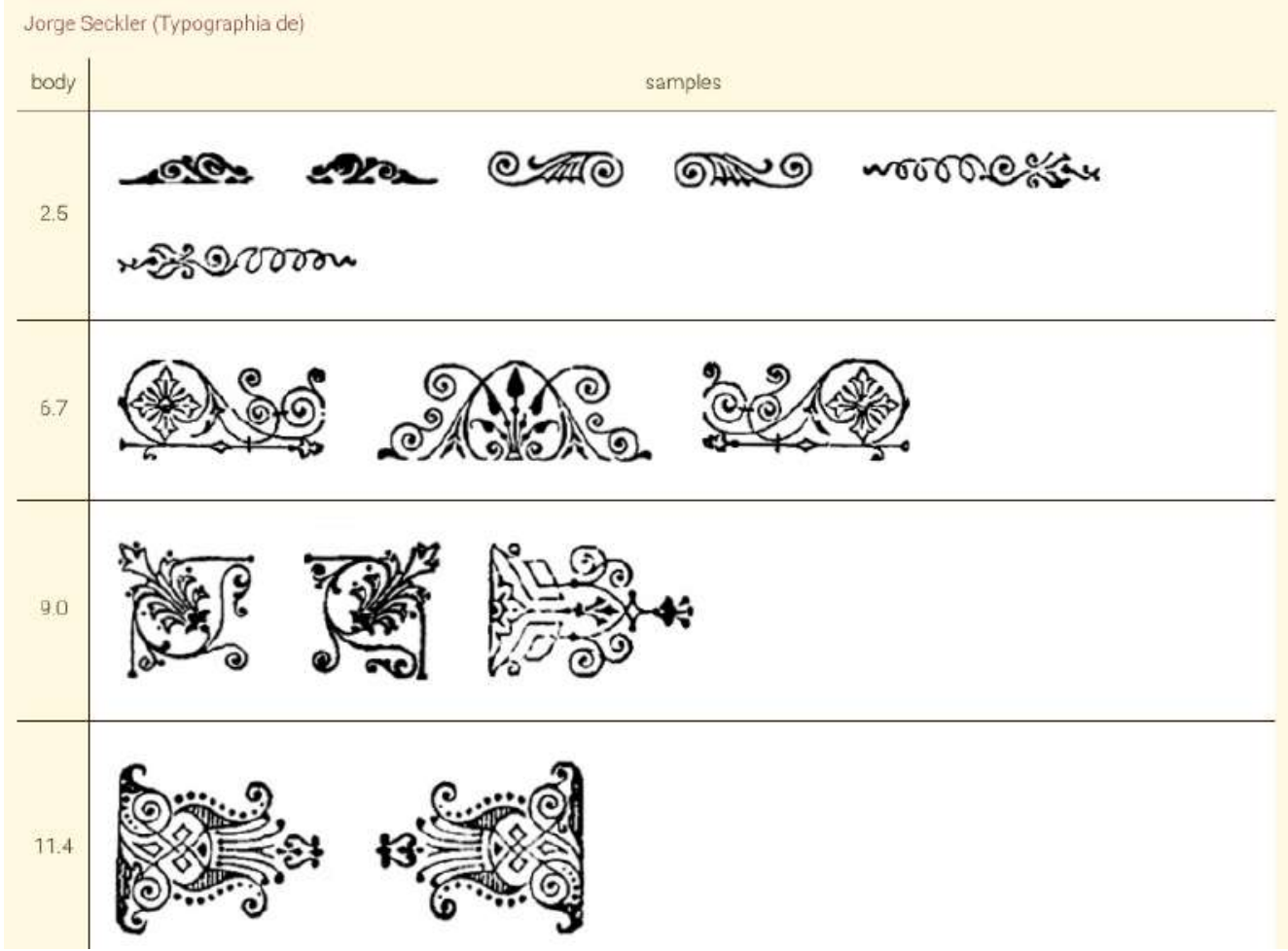

Figure 4: Ornament sample in the Tipografia Paulistana website. 


\title{
Jorge Seckler (Typographia de)
}

\author{
Since: 1865 \\ Until: 1890 \\ Activities: Typography, Lithography, Book binding
}

The first mention of a printing shop belonging to Jorge Seckler, in São Paulo commercial almanacs, occurs in 1865 . Seckler is indicated as the owner of a business by his name, established at 58 São Bento street. Between 1872 and 1878 Seckler presents himself as the owner of Typographia Livro Verde ('green book' letterpress printing shop), an establishment that also offered books, office supplies, bookbinding and ruled paper, located at Direita (straight) street, number 14/15 - the same address where Henrique Schroeder's Typographia Allemā (German printing shop), which by then was transferred to Commercio (commerce) street, previously operated. In 1882, Seckler announces in his new almanach that he now owns five mechanical presses, and an office separated from the printing shop, located at 25 de Março (25 March) street, number 2. From the following year, he announces his company as Typographia a Vapor de Jorge Seckier \& C. (Jorge Seckier \& Company Steam Typography). The address changes again in 1887, passing to numbers 38 and 40 of the same 25 de Março street, maintaining the premises in Direita street. In 1887 he claims to be the owner of the "first and best-fumished establishment for typography. bookbinding, paper ruling and manufacturing of blank books in the province - a house founded in 1862, and, in 1889, he informs that the company would have been awarded in various national and foreign exhibitions". In the São Paulo State Almanach for year 1891, the Companhia Industrial de S. Paulo (Sâo Paulo industrial Company) printing shop, which would publish the ninth and tenth volumes of Seckler's almanacs, is described as "successor to Jorge Seckler \& C. and Baruel \& C:" having as their address the "old Seckler house". located at number 14 Direita street.

\section{Address}

Rua Sầ Bento, 58 (1865 a 1865)

Rua Direita, 15 (1873 a 1883)

Primeiro endereço da Allemä

Rua 25 de Março, 2 (1882 a 1883)

Escritório na Rua Direita, 15.

Rua 25 de Março, 38-40 (1883 a 1890)

Escritóno na Rua Direita 14

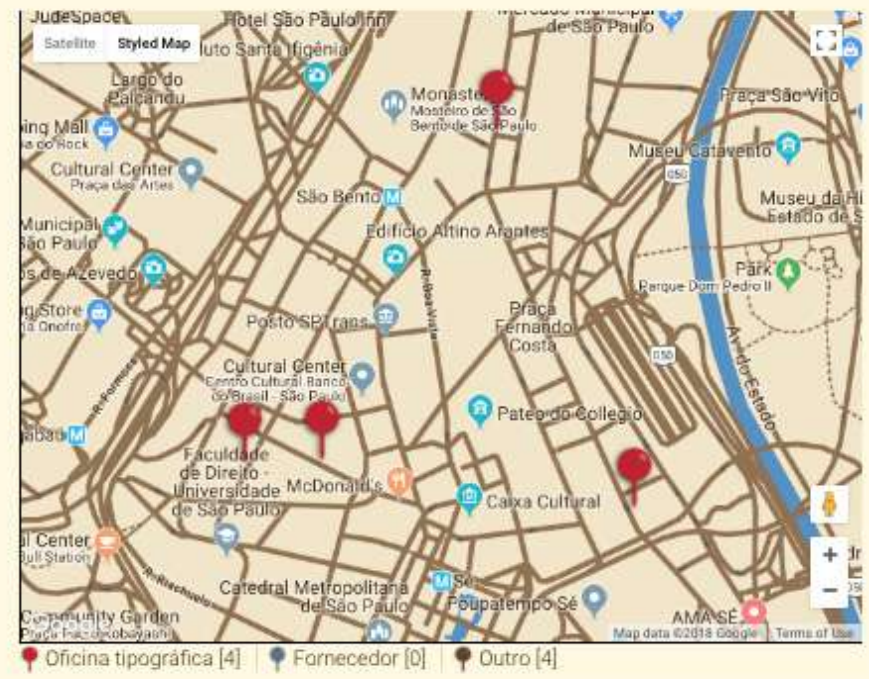

\section{Typefaces}

\section{A}
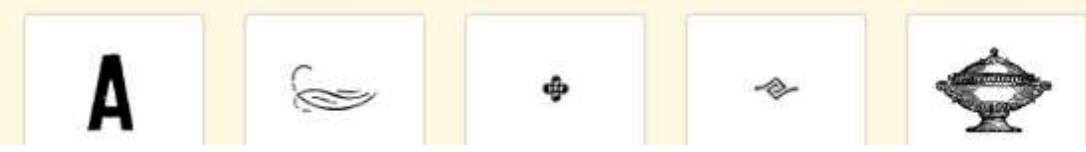

Figure 5: Page dedicated to Jorge Seckler printing shop in the Tipografia Paulistana website. 
Interactive maps, based on Google Maps, were customized, associated with time bars (linear graphs controlled by sliders) and check-box filters, and made available as a navigation mode in the Companies and Typefaces areas. Early examples of the use of maps for the visualization of historical data related to print culture include Lucien Febvre and Henri-Jean Martin's maps of European printing offices up to 1500, published in their influential L'apparition du livre (1958), and Michael Twyman's study on the location of London lithographic printers (Twyman 1976). In both cases, series of static maps were used as visual evidence for arguments on the spread of printing and its consequences.

More recent efforts towards spatializing print history include interactive maps such as the History of the Bulgarian Book Between the Liberation and Independence (1878-1908), ${ }^{4}$ and the Atlas of Early Printing. ${ }^{5}$ Both of them offer the possibility of multiple visualizations of the maps, combining time (control of the years or periods to be considered) and the location of printing shops and related institutions and businesses (like publishers, book binders, universities, paper mills and fairs, for more details see Farias, Hanns and Dixon 2016). In the case of the Bulgarian map, images of title pages of books produced by the printing shops along the years within the time bar are also available.

In the Tipografia Paulistana website Companies area, a time bar on the top of the map (Figure 6) allows the user to restrict the view to a specific time period or to a single year (Figure 7). The customized pins shown in the Companies map differentiate letterpress printers (in red), type foundries and distributors (in blue) and other related business (like bookstores, book binders and lithographic printers, in brown). The total number of companies and counts of each kind of business is provided below the map. Clicking on a pin in the map provides a short description of the business (Figure 7) and a link to the company page.

4 Available since 2011 at <https://bgbookhistory.unibit.bg/en>.

5 Available since 2013 at <http://atlas.lib.uiowa.edu>. 


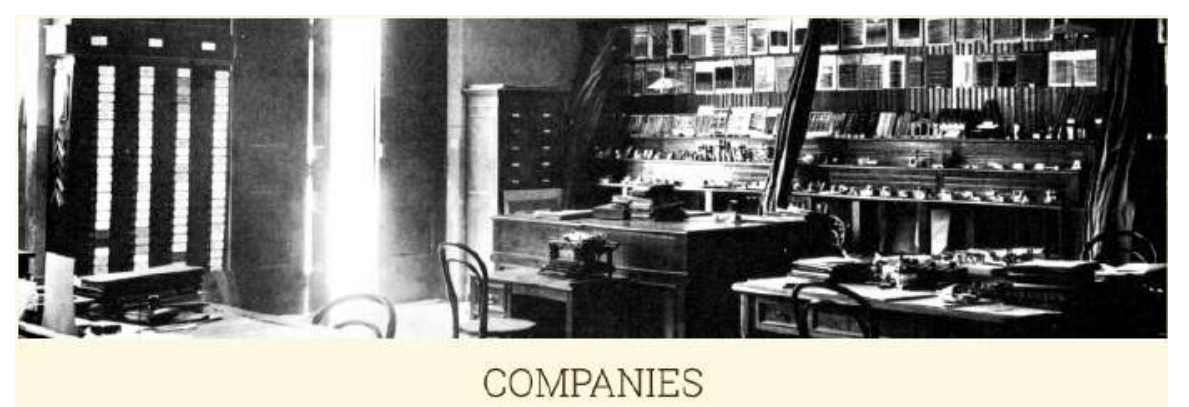

Leterpress printers, type foundries and distributors in operation in the cry ot Sao Paulo between 1827 and 1927

Q MAP $\equiv$ UST

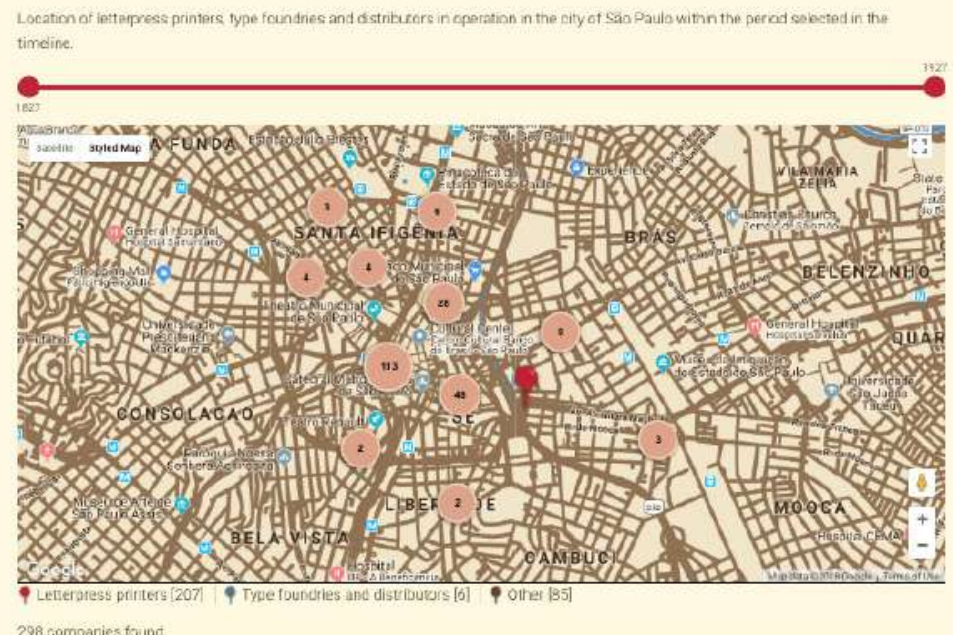

Figure 6: A map with all the companies found within the time frame of the research (1827-1927). 


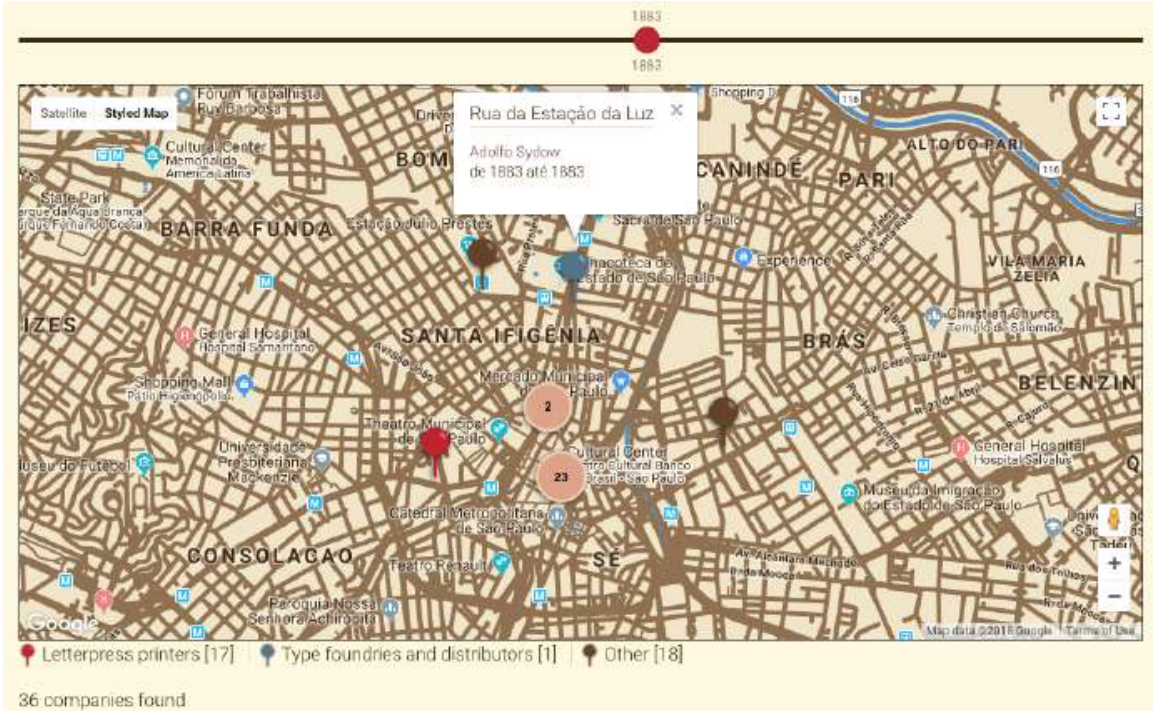

Figure 7: A map showing the companies found to be active in year 1883.

In the Typefaces area, besides selecting a year or a period, it is also possible to apply filters that restrict type family category or formal attributes. The resulting map will show the addresses of the companies known to have used or produced typefaces that comply with the filters within the time span indicated in the time bar. Below the map, a mosaic of the typefaces will be displayed. Figure 8 shows an example of a map for fantasy typefaces, with one of the pins selected.

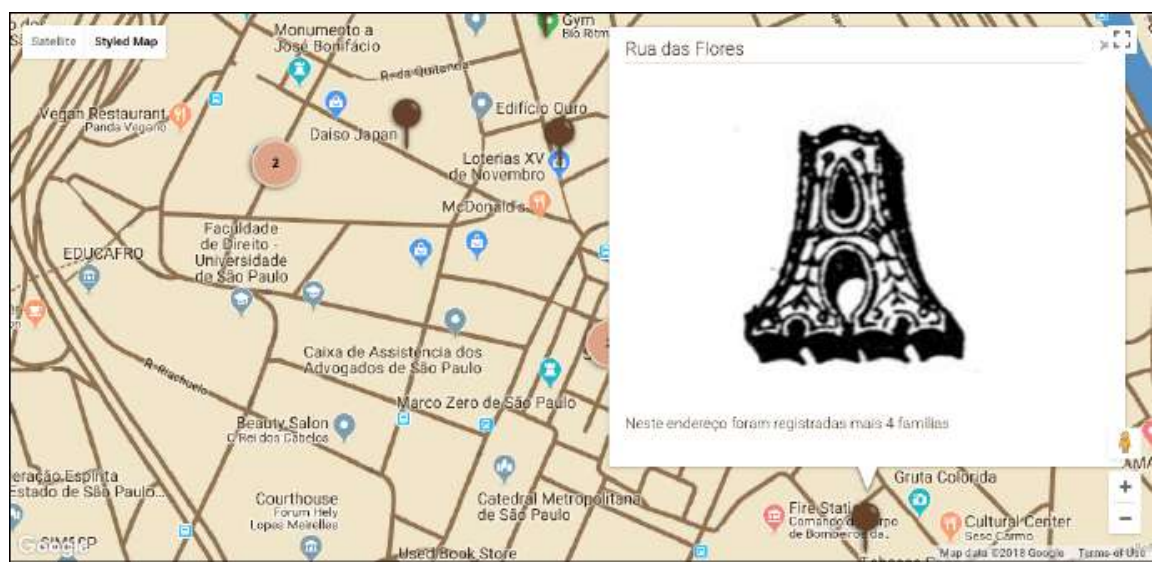

Figure 8: A map showing the location of companies that used fantasy typefaces, with one of the pins selected. 
Finally, a timeline of all letterpress printers and type vendors (type foundries, distributors and importers) was developed using Google Spreadsheets (Figure 9). Years were indicated in columns, and the start of every decade, as well as the opening of every decennial, from 1827 to 1927, were highlighted.Companies were accommodated in lines, with boxes extending from the first to the last year of which it was possible to ascertain that the business was active. Eventual successors of the same company were given boxes in the same line. Two shades of gray were used for printing shops, a shade of green for type foundries or vendors, and a shade of blue for companies that were both printing and selling type. This timeline was made accessible from the left hand side menu of the Tipografia Paulistana website, and also from the topic Research in its home page.

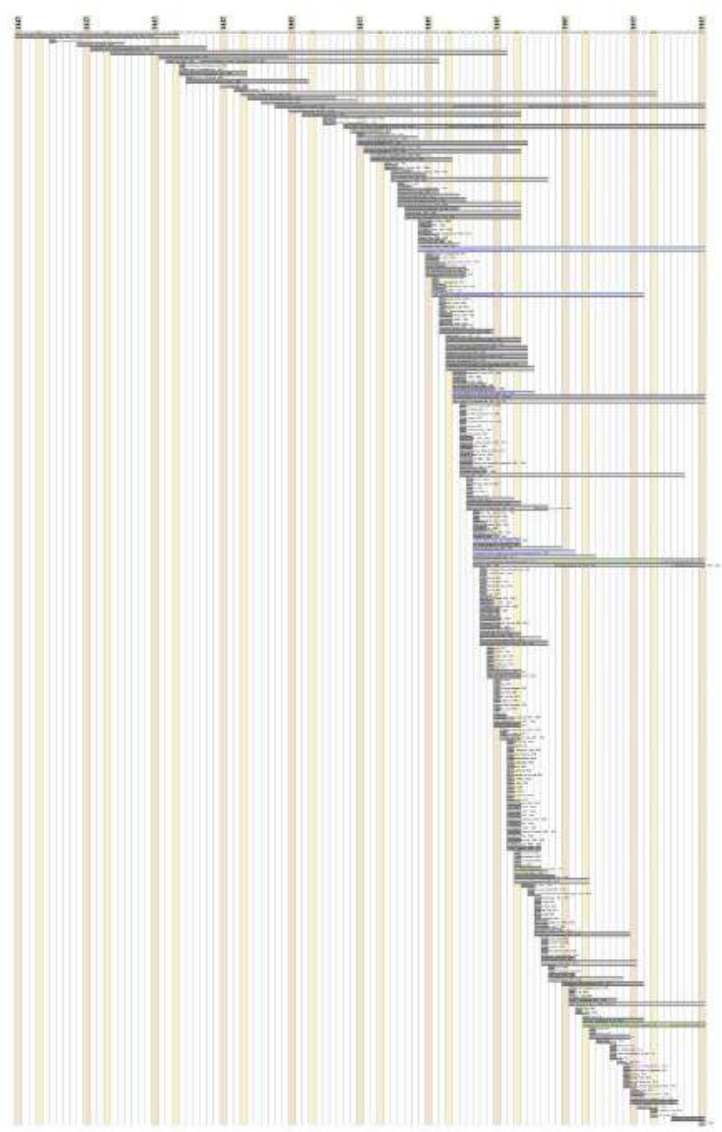

Figure 9: Timeline of the letterpress printing shops and type vendors active in São Paulo from 1827 to 1927. 


\section{ANSWERING THE RESEARCH QUESTIONS}

The strategies of visualization adopted all along the research process were key for dealing with the expressive amount of data gathered for answering the four research questions.

\section{Who?}

The use of colour coded spreadsheets and maps associated with timelines was key for answering the first question. The lists of letterpress printers and type vendors were organized and checked with the help of spreadsheet tools (such as filters and sorting), and the use of maps helped in the identification of businesses that had slightly different names but occupied the same address in the same time span - an indication that they were in fact the same business.

Until may 2018, a total of 317 companies were identified. Among them, 270 letterpress printers, 11 type vendors (5 of them also active as printers) and 3 type founders (the religious school Liceu Sagrado Coração de Jesus, and the companies owned by immigrants of italian origin A. Ardinghi and R. Cardinale, the last one producing wood type).

\section{When?}

As the timeline in Figure 8 dramatically shows, the temporal distribution of those companies in the period studied was not at all uniform. A staggering increment in the number of companies can be identified from around 1880 to 1900 . The number of type vendors (foundries or distributors) also grows dramatically, although in a much smaller proportion, and with some delay (see green and purple lines in Figure 9 and table 1).

Because the type samples used to rebuild the printers' typographic repertoires were extracted from dated documents, it was possible to precisely track the use of typefaces along the research time span. This allowed for the configuration of tables highlighting the dates when the typefaces were used (an example is given in Figure 10), that helped in understanding how fast and in what pace the repertoire of a certain printer was created. 


\begin{tabular}{|l|l|l|}
\hline Period & Printing offices & Type vendors \\
\hline $1827-1837$ & 3 & 0 \\
\hline $1838-1847$ & 4 & 0 \\
\hline $1848-1857$ & 12 & 0 \\
\hline $1858-1867$ & 12 & 0 \\
\hline $1868-1877$ & 16 & 0 \\
\hline $1878-1887$ & 41 & 1 \\
\hline $1888-1897$ & 135 & 7 \\
\hline $1898-1907$ & 108 & 8 \\
\hline $1908-1917$ & 106 & 6 \\
\hline $1918-1927$ & 20 & 4 \\
\hline Total & 270 & 11 \\
\hline
\end{tabular}

Table 1: Number of printing offices and type vendors (foundries or distributors) per period

\begin{tabular}{|c|c|c|c|c|c|c|c|c|c|}
\hline & 1854 & 1895 & 3887 & 1888 & 1890 & 3891 & 1895 & 1896 & ocorrénass totes \\
\hline \multicolumn{10}{|l|}{ grupo 1 -tescanas goticas. } \\
\hline & 1 & 1 & 5 & s & 4 & 3 & 1 & 1 & 24 \\
\hline & & & 1 & & & & & & 1 \\
\hline & 3 & 2 & & & & & & & 5 \\
\hline \multicolumn{10}{|l|}{ 8upo 2 -serifa trienguler } \\
\hline & & & 1 & 1 & & & & & 2 \\
\hline DESS & & & & 1 & 1 & 1 & 1 & & 4 \\
\hline \multicolumn{10}{|l|}{ Erupo 3 - biturcapho ang Lasr } \\
\hline JOSÉ ANTONIO DA SILVA & 5 & & & & & & & & 5 \\
\hline fomplebo em Hovais & 3 & 1 & & 1 & & & & & 5 \\
\hline PHOTORRAPHU ALILEA & & 1 & & & & & & & 1 \\
\hline \multirow{2}{*}{\multicolumn{10}{|c|}{ 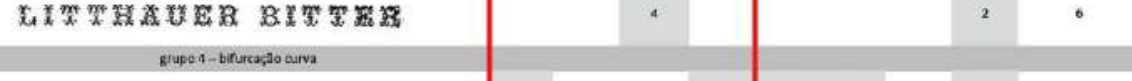 }} \\
\hline & & & & & & & & & \\
\hline E. EESNEES \& & 2 & & & 1 & 1 & 1 & & 1 & 6 \\
\hline & 1 & 3 & 9 & 8 & 9 & 8 & 2 & 3 & 43 \\
\hline \multirow[t]{2}{*}{ RTIA XIR.BTT.A. N. 32} & 9 & 2 & 12 & 9 & 11 & 11 & 1 & $B$ & 61 \\
\hline & 21 & 10 & 32 & 29 & 26 & 24 & 5 & 13 & 163 \\
\hline
\end{tabular}

Figure 10: Table showing the use of tuscan typefaces in the almanachs published by Jorge Seckler and his successors, highlighting the period during which those typefaces first appeared. 


\section{Where?}

The implementation of interactive maps in Tipografia Paulistana website allowed for the combined visualization of geographic and temporal data. Controlling the time track handles it is possible to see, for instance, that, while there is a definite concentration of companies near Sé square (the historical city central point, note the circle with number 113 in Figure 11), the exclusive concentration in this specific site lasted only from 1827 to 1865 (Figure 12). In 1870 companies moved towards Santa Ifigênia and Liberdade districts (Figure 13), and, from 1880 on they spread even further, towards the Easter districts of Mooca and Braz, the Southern district of Bela Vista, and the Northern district of Campos Eliseos (Figure 14).

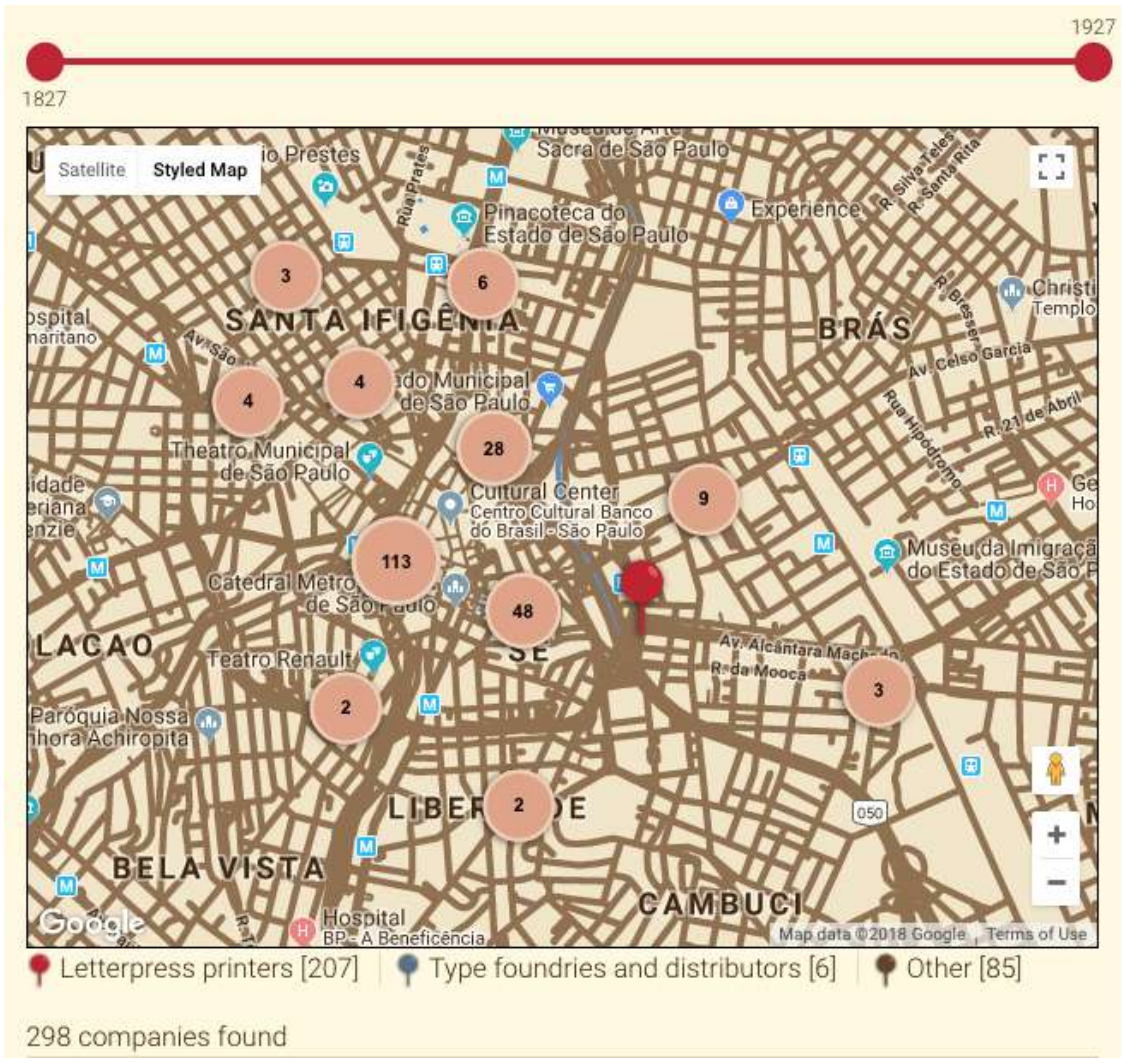

Figure 11: Location of the companies active in São Paulo during the whole time span. 


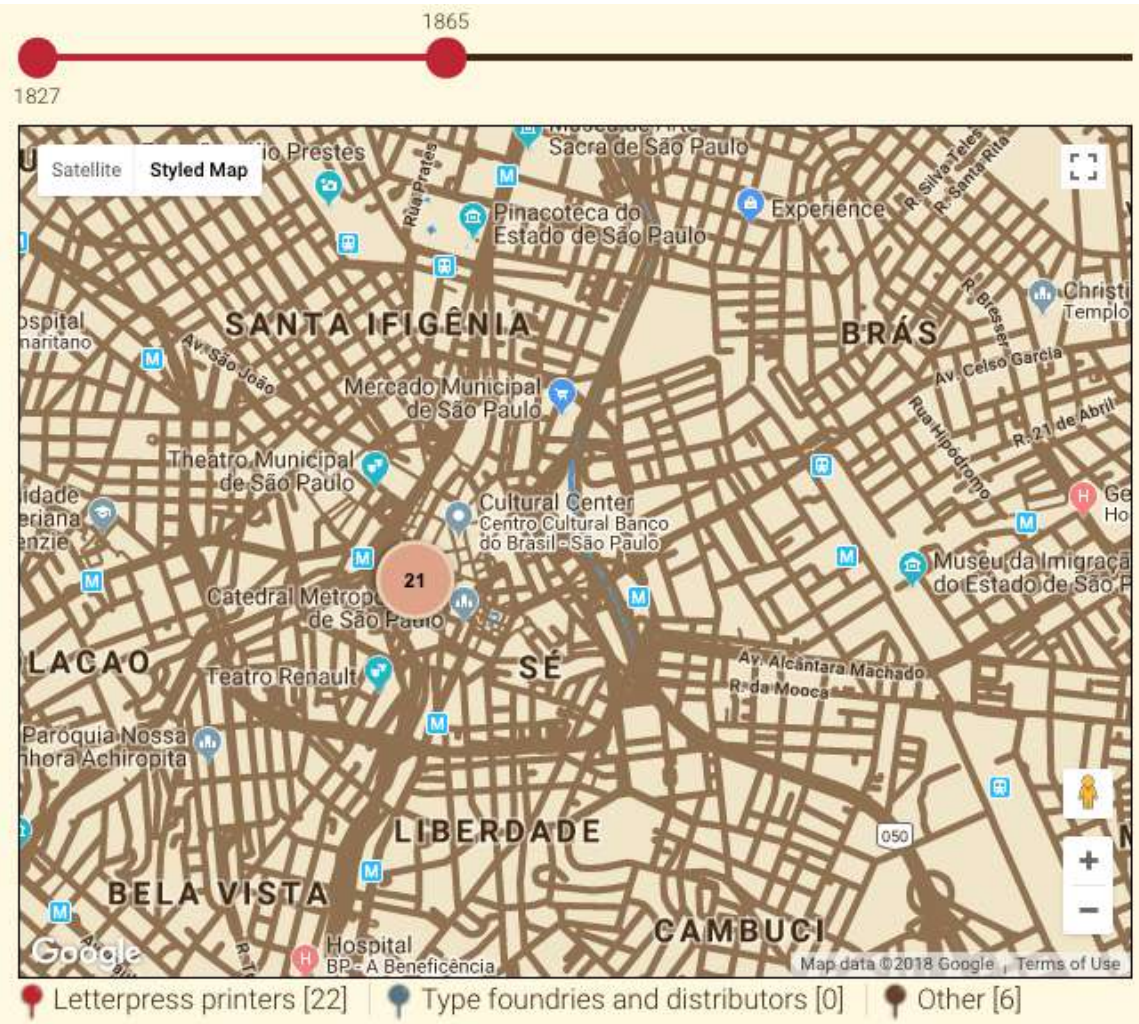

28 companies found

Figure 12: Location of the companies active in São Paulo from 1827 to 1825. 


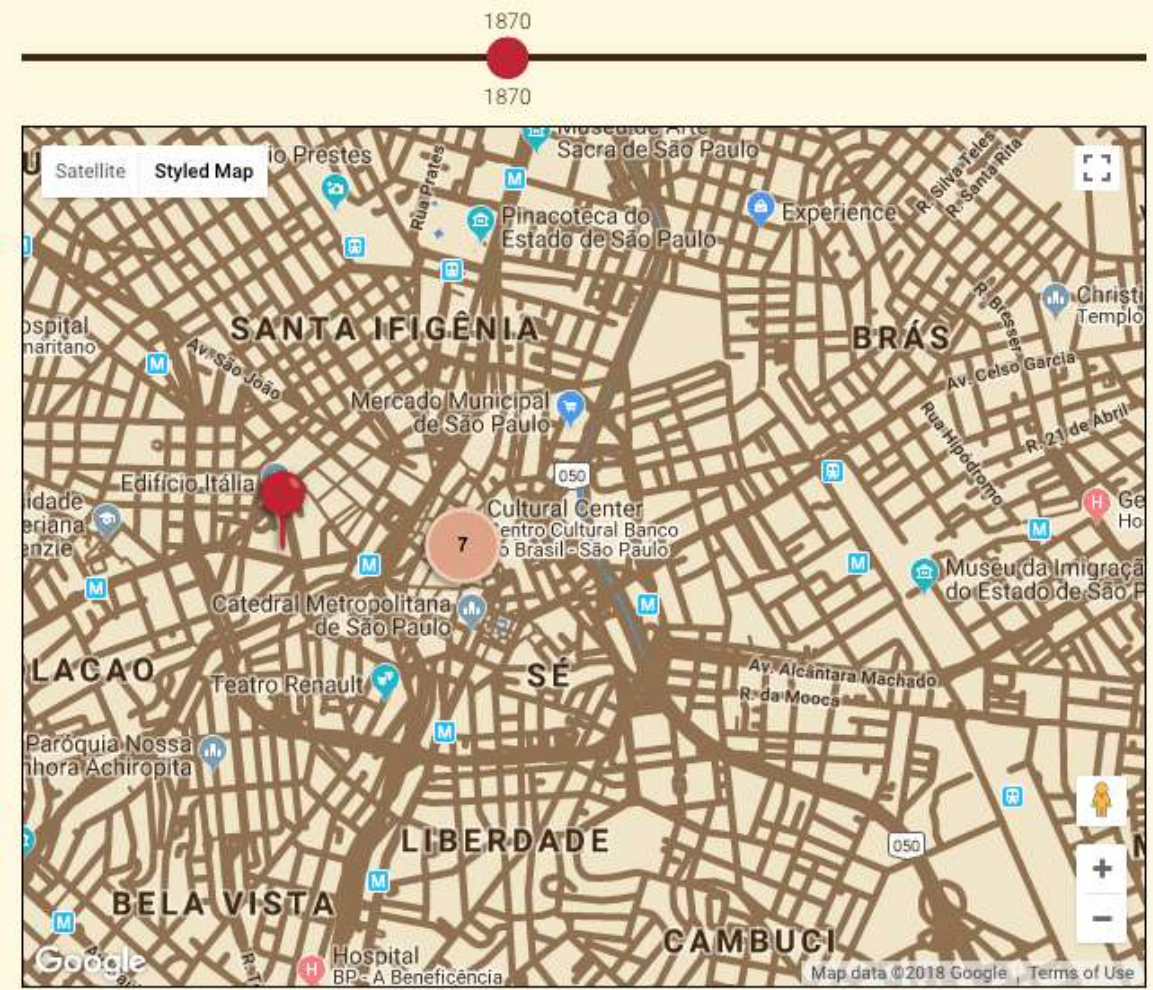

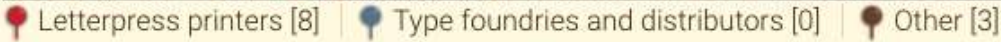

11 companies found

Figure 13: Location of the companies active in São Paulo in 1870. 


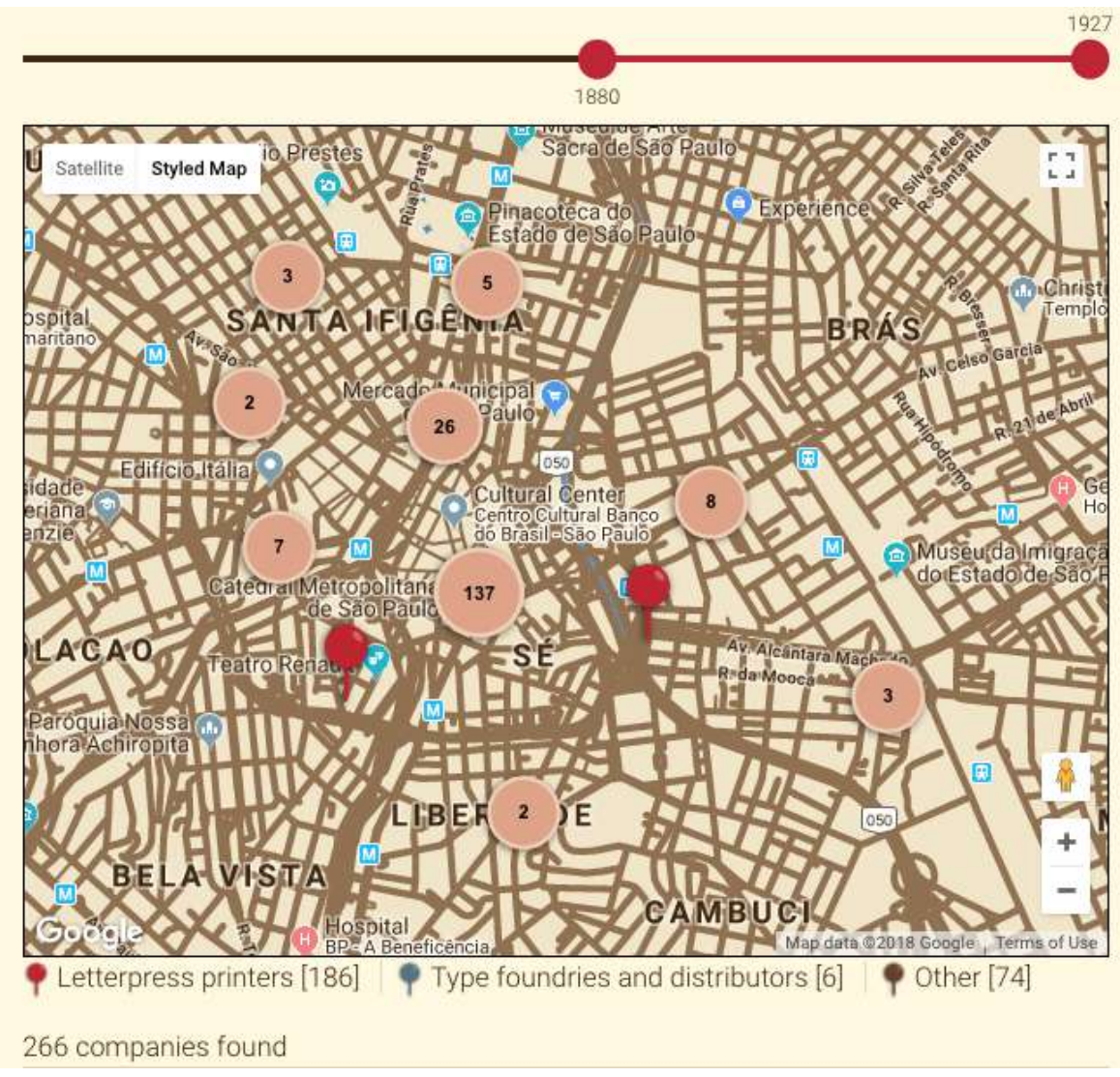

Figure 14: Location of the companies active in São Paulo from 1880 to 1927.

This is coherent with the spread of the city during the same years, and shows that, while some businesses would go on to be established in more periferic and industrial areas, others would stay closer to the city center. Older and bigger companies, like Jorge Seckler's Typographia a Vapor (later to be known as Companhia Industrial de São Paulo, and Duprat and Co.) would eventually have two addresses: an office located in the city centre, and a workshop or warehouse further away.

\section{What?}

The strategy for visualizing data that could answer the last question ("what typefaces were São Paulo printers using?”) consisted, as explained before, in re-building the printers' type specimens from printed matter issued from their presses (so far, almanachs and newspapers). This has revealed to be the most challenging task faced by the research team, once extreme care must be taken to 
guarantee that data collected in different occasions by different researchers can be compared, and complex data interaction must be devised and programmed.

Even if a complete answer for the question cannot be given at this point (the repertoire of just 4 of the more than 200 printers had been retrieved), some trends and coincidences could be noticed. Those early printers would use more extensively serifed typefaces, in particular for text but also for title, but with little variation - a couple of such typefaces, in different sizes, would be used in all publications. Fantasy typefaces are the most varied. Those belonging to families with more variation of size were used more frequently, in particular in almanachs, and in many, if not all, publications by the same printer. Some fantasy typefaces ${ }^{6}$ appear only once or twice, always for the name of the same advertiser, suggesting an strategic repetition that would create a stable visual identity for a product, service or commerce. Script faces were rare, although quite varied. The earliest example - one size in copperplate script style - appears in an almanac published in 1857. Other script typefaces, most of them fraktur variations, in one or two sizes, appear in the repertoire of Jorge Seckler, from 1878 on. Sans serif faces were even more rare, available in just one or only a few sizes, and used sparcelly, since 1857.

\section{CONCLUSION}

Research on graphic memory deals. essentially, with visual data, and therefore can benefit from the application of old and new visualization strategies and techniques. Through the website Tipografia Paulistana, an expandable database on letterpress printing in São Paulo in the nineteenth and early twentieth century was made available. The website development also resulted in the elaboration of new techniques for the visualization of georeferenced historical data and typographic repertoires, which are the most relevant results for the field of information design. Those visualization strategies and techniques helped in the organization and analysis of the data gathered, providing clues and evidences for interpretation.

An important limitation of the research presented here is the relatively small number of typographic repertoires catalogued so far (namely, those of Jorge Seckler and his successors, Imparcial de Marques e Irmão, O Farol Paulistano and Typographia Allemã), and the still partial nature of the cataloguing (not all outputs of their presses has been examined). Another limitation is the still work-in-

${ }^{6}$ For a more detailed survey on the use of tuscan typefaces, see Farias and Cunha Lima 2016. 
-progress nature of the digital platform. Although the UX team worked hard to overcome all technical problems indicated in usability testing and by members of the research team, new issues arise constantly as the platform is feeded and consulted.

The development of other visualization techniques, like automatic timelines and networks, already devised by the research team, but not implemented due to time constraints, is one of the key aspects of further research.

\section{ACKNOWLEDGEMENT}

Research supported by the São Paulo Research Foundation (FAPESP) Regular Research grant 2010/19166-8, and by the Brazilian National Council for Scientific and Technological Development (CNPq) Universal grant 462760/20146 and Research Productivity fellowships 304143/2013-8 and 311964/2016-8.

\section{REFERENCES}

Annenberg, M. 1994 [1975]. Type foundries of America and their catalogs. New Castle: Oak Knoll.

Camargo, A. M. A. 1983. Os primeiros almanaques de São Paulo: introdução à edição fac-similar dos almanaques de 1857 e 1858. São Paulo: Imprensa Oficial do Estado de São Paulo.

Cunha Lima, E. L.; Aragão, I. R. and Farias, P. L. 2013. Describing movable type specimens: a contribution to Brazilian (tipo)graphic memory. In: FADEL, L. M.; SPINILLO, C. G.; MOURA, M. and TRISKA, R. (Org.). Selected Readings of the 5th Information Design International Conference: research and practice: 233-249. Florianópolis: SBDI.

Cruz, H. de F. 2004. A imprensa paulistana: do primeiro jornal aos anos 50. In: P. Porta (org.). História da cidade de São Paulo, v. 2: a cidade no império (1823-1889): 351385. São Paulo: Paz e Terra.

Deaecto, M. M. 2002. Comércio e Vida Urbana na Cidade de São Paulo (1889-1930). São Paulo: Senac São Paulo.

Dixon, C. 2001. A description framework for typeforms: an applied study. PhD thesis, Central Saint Martins / University of the Arts London.

Farias, P. L. 2015. On graphic memory as a strategy for design history. In: Tradition, Transition, Trajectories: major or minor influences? [= Proceedings of the 9th Conference of the International Committee for Design History and Design Studies, Aveiro]: 201-206. São Paulo: Blucher.

Farias, P. L.; Aragão, I. R. and Cunha Lima, E. L. 2012. Unravelling aspects of Brazilian design history through the study of 19th century almanacs and type specimens. In: Conference Proceedings: Design Research Society 2012: Bangkok, vol. 2: 498-511. 
Farias, P. L. and Cunha Lima, E. L. 2016. Transatlantic eccentricities: tuscan typefaces as an example of transnational typographic taste. Communication Design, v. 4(1/2): 4-20.

Farias, P. L.; Hanns, D. K. and Dixon, C. 2016. Spatializing design history: considerations on the use of maps for studies on print culture. In: Proceedings of the 10th International Conference on Design History and Design Studies, Taipei: 348-353. São Paulo: Blucher.

Farias, P. L. and Onoda, M. A. 2015. Letras toscanas no repertório tipográfico de Jorge Seckler (1883-1895). In: Proceedings of the 7th Information Design International Conference, Brasilia: 883-893. São Paulo: Blucher.

Freitas, A. A. de 1915. A imprensa periódica de São Paulo desde seus primórdios em 1823 até 1914. São Paulo: Typ. do Diário Official.

Febvre, L. and MARTIN, H. J. 1958. L'apparition du livre. Paris: Albin Michel.

Gray, N. 1976 [1938]. Nineteenth century ornamented typefaces. Berkeley: University of Califórnia.

Hallewell, L. 1985. O livro no Brasil: sua história. São Paulo: Edusp.

PROTHERO, G. W. 1888. A memoir of Henry Bradshaw: Fellow of King's College, Cambridge, and University Librarian. London: K. Paul, Trench, and co.

Twyman, M. 1976. A directory of London lithographic printers, 1800-1850. London: Printing Historical Society.

Vervlift, H. D. L. 2008. The palaeotypography of the French renaissance: selected papers on sixteenth-century typefaces. Leiden: Brill. 